1922 and until his retirement in 1943 was in charge of the grants to postgraduate students for training in research, to individual research workers and the grants to the co-operative research associations. $\mathrm{He}$ thus assumed responsibility, without any industrial background, for the research association movement in Britain at the most critical and difficult period of its history.

The novelty of this scheme for Government assistance to research in industry was wearing off, and the post-war boom years were coming to an end. Industry was generally indifferent to science and often suspicious of the co-operative aspect of the associations. Money was tight both in industry and Government, and the associations were compelled to function with very limited resources. Most of them were doing useful work, as evidenced by the book Hetherington wrote with Sir Frank Heath on their early history; but the results achieved were seldom of a kind to make a ready appeal to industrialists imbued with a profound faith in traditional methods. It was largely due to Hetherington's skill as an administrator and to his personality that the movement survived these lean years to play a notable part in the Second World War. His work demanded much tact and patience--virtues which did not come to him naturally. It was a great satisfaction to him to see the associations expand after the War to occupy the important position in British industry they hold to-day.

Hetherington's early training fitted him admirably to deal with the scientific grants to individuals; but even here he had his difficulties, as during the 30's more than one influential, but unenlightened, Civil Servant made no secret of his opinion that many of the grants, especially those for training research students, were little more than unemployment doles.

Hetherington's official work was lightened by two hobbies. The first was his keen interest, as collector and expert, in Chinese porcelain. In this field his important book, written with R. L. Hobson, on "Early Ceramic Wares of China" brought him an international reputation. He also took a leading part in the formation of the Oriental Ceramic Society. His second interest was in turning on the lathe. Here recognition of his skill led to his becoming a Master of the Tumers' Company, the honorary freedom of which was bestowed on him in 1932. He took special interest in the turning properties of many little-known Empire timbers.

Finally, Hetherington had quite a talent for versification, and frequently amused his colleagues with mildly satirical verses on matters of topical interest to the Department of Scientific and Industrial Research.

O. F. BROWN

\section{Dr. W. D. Douglas}

The death on August 5 of Dr. W. D. Douglas removes another of the now thinning ranks of firstgeneration aircraft scientists. $\mathrm{He}$ was born in Ireland on August 2, 1887, and educated as an electrical engineer at Trinity College, Dublin. For some years he served as a hospital X-ray operator, and then joined the staff of the Royal Aircraft Estab. lishment and specialized in the properties of materials, especially timber and adhesives, which were the common materials of aircraft structures. He became a leading authority on their properties.
In the 1930 's, he was in charge of the mechanical testing of aircraft structures and components and materials. Under his guidance the science of testing large structures grew from small beginnings to something like its present degree of sophistication. His advice on the design and strengthening of structures was eagerly sought by aircraft designers.

Douglas's knowledge of the mode and cause of failure of materials was invaluable to the Air Ministry's Accident Investigation Department, and it became usual for the pieces of crashed aircraft to be sent to him. After painstaking re-assembly and examination of scratches, dents and fractures, he was often able to decide the sequence of catastrophe and the cause of failure. The techniques he developed form the basis of present-day aircraft accident investigation. Re-organization during the Second World War put Douglas in charge of the Materials Department at the Royal Aircraft Establishment, the three divisions of which covered chemistry, metallurgy and non-metallic materials.

On retiring from the Civil Service in 1946, Douglas joined the furniture firm of Harris Lebus as its first head of research. In this unique position he spent nine fruitful years, asking questions, seeking answers and giving sound advice. He represented the firm on technical committees, and when the Furniture Development Council was started in 1949, Douglas joined its research committee and was most helpful in formulating programmes and in guiding the Council's research officers. He played a major part in the development of the performance tests for furniture, which are now incorporated in British Standard Specifications. Furniture satisfying the standards is marketed under the 'Kite' mark.

Douglas retired from Harris Lebus in 1955, but continued to serve most effectively on the Furniture Development Council.

In personal characteristics he was a modest man, and the most helpful and sincere of friends to those in need; but he could also be a worthy adversary. A devoted husband and father, he leaves a widow and son.

C. Gurney

\section{Dr. Peter L. Goldacre}

Dr. Peter L. Goldacre, a senior research officer in the Division of Plant Industry of the Commonwealth Scientific and Industrial Research Organization, Canberra, Australia, died after a brief illness on April 16, at the age of thirty-four. Paradoxically, at the time of his death from cancer, he was engaged in incisive and rewarding investigations into the nature of the chemical factors controlling cell division in plants.

Goldacre was educated at Sydney Boys' High School and the University of Sydney. He joined the Division of Plant Industry of the Commonwealth Scientific and Industrial Research Organization, in 1947, as one of the first two plant biochemists to be appointed to this agency. His early work, reflecting his biochemical training, was largely enzymological. He was the first to characterize the "indoleacetic acid oxidase' complex as being composed in part of a peroxidase. Later, at the California Institute of Technology, where he obtained his Ph.D. degree in 1952, he was instrumental in discovering the activating effect of substituted monophenols on this enzyme complex. During these investigations, he also discovered that 2,4-dichlorophenol is a specific inhibitor 